\title{
Production of Nuclease Activity in U937 Cells by Phorbol 12-Myristate 13-Acetate and Lipopolysaccharide
}

\author{
Hyung-Joo Kwon ${ }^{\dagger}$ and Doo-Sik Kim ${ }^{\dagger} * *$ \\ $\dagger$ Institute of Life Science and Biotechnology and *Department of Biochemistry, \\ College of Science, Yonsei University, Seoul 120-749, Korea
}

Received 28 February 2003, Accepted 18 April 2003

\begin{abstract}
The proliferation and differentiation signals of myelogeneous U937 cells are provided by extracellular stimuli, such as lipopolysaccharide (LPS) and phorbol 12myristate 13-acetate (PMA). In a DNA-nativepolyacrylamide gel assay system, we demonstrated that a particular nuclease activity is expressed in PMAstimulated U937 cells and secreted into the culture medium. The nuclease activity was induced in U937 cells by LPS treatment, while the secretion of the enzyme was undetected in the culture medium. Therefore, it is likely that the expression and secretion of the particular nuclease in U937 cells are controlled by extracellular stimulations, such as PMA and LPS treatment.
\end{abstract}

Keywords: Differentiation, DNA-native-PAGE, Endonuclease, U937 cells

\section{Introduction}

Deoxyribonucleases from human tissues (Yasuda et al., 1990; Yasuda et al., 1992; Ribeiro and Carson, 1993) have been characterized as existing in multiple forms. A human protein that is homologous to DNase I has been cloned and partially characterized in tissues (Zeng et al., 1997). Recombinant human DNase I was approved for clinical use in the treatment of cystic fibrosis. This enzyme hydrolyzes the extracellular DNA that was found in sputum obtained from patients with cystic fibrosis, and reduces the viscosity of cystic fibrosis sputum in vitro (Shak et al., 1990).

The discovery that DNase I activity is widely distributed in human tissues and body fluids, other than just in the digestive system (Nadano et al., 1993; Yasuda et al., 1993), may

*To whom correspondence should be addressed.

Tel: 82-2-2123-2700; Fax: 82-2-312-6027

E-mail: dskim@yonsei.ac.kr indicate additional in vitro physiological functions of the nuclease. Our recently established nuclease assay system, using DNA-native-polyacrylamide gel electrophoresis (DNAnative-PAGE), is suitable for the identification of the particular nuclease activity in human B-lymphoblastic IM9 cells (Kwon and Kim, 1998). The nuclease activity that we found in IM9 cells is distinct from that of DNase I and other nucleases that have been reported, including the optimal $\mathrm{pH}$ that is required for catalysis, cation dependence for enzyme activity, electrophoretic mobility in native-PAGE, and immunochemical properties.

The human monocyte cell line U937 cells, derived from the pleural fluid of a patient with diffuse histiocytic lymphoma, have served as a model for monocyte-macrophage differentiation (Sundstrom and Nilsson, 1976). U937 cells undergo a wide variety of phenotypic and functional changes in the presence of PMA (Hass et al., 1989). These changes include the loss of proliferative potential, adherence, and the acquisition of many effector functions that are characteristic of activated macrophages, such as antibody-dependent cellular cytotoxicity, respiratory burst, and augmented release of IL-1. Because of the functional and phenotypic differences that depend on PMA treatment, the U937 cell line provides an ideal model for studying the changes in intracellular events that take place during differentiation. In the present communication, we demonstrate that the biosynthesis and secretion of a particular nuclease activity remarkably increased in PMA-induced U937 cells.

\section{Materials and Methods}

Cell culture and treatment The U937 cell line was obtained from the American Type Culture Collection (ATCC, Manassas, USA). The cells were maintained at $5-9 \times 10^{5}$ cells $/ \mathrm{ml}$ in a RPMI 1640 medium that was supplemented with $10 \%$ heat-inactivated fetal bovine serum (FBS, Life Technologies, Grand Island, USA), $2 \mathrm{mM}$ glutamine, $100 \mathrm{U} / \mathrm{ml}$ penicillin, and $100 \mu \mathrm{g} / \mathrm{ml}$ streptomycin. 
Viability was assayed using trypan blue dye exclusion, and was typically greater than 95\% (Kim et al., 2001; Kim et al., 2002). Differentiation of the U937 cells was induced for the indicated time intervals in a fresh culture medium that contained 1-10 ng/ml PMA (Sigma, St. Louis, USA; Han et al., 2002). LPS and cycloheximide were used at the final concentrations indicated: $10 \mathrm{ng} / \mathrm{ml}$ LPS (Sigma, St. Louis, USA), $10 \mu \mathrm{g} / \mathrm{ml}$ cycloheximide (Sigma, St. Louis, USA). Cytocentrifuge preparations were stained with Wright-Giemsa for differentiation analysis.

Preparation of culture medium and cell lysates The U937 cell culture medium and cell lysates were prepared as previously described (Kwon and Kim, 1998). The culture medium was centrifuged for $5 \mathrm{~min}$ at $1,500 \mathrm{rpm}$ to remove cells and/or cell debris. The cells were then washed twice with cold phosphatebuffered saline, and resuspended at $1 \times 10^{7} \mathrm{cells} / \mathrm{ml}$ in a $0.5 \%$ Nonidet P-40 buffer that contained $150 \mathrm{mM} \mathrm{NaCl}, 10 \mathrm{mM}$ Tris-Cl, $\mathrm{pH} 7.5$, and $1 \mathrm{mM}$ PMSF. Following a 15 min-incubation at $4^{\circ} \mathrm{C}$, the lysed cells were centrifuged at $12,000 \mathrm{rpm}$ for $15 \mathrm{~min}$ at $4^{\circ} \mathrm{C}$, and the supernatant was used as a cell lysate. The recovered culture medium and lysates were stored at $-20^{\circ} \mathrm{C}$.

Determination of nuclease activity in DNA-native-PAGE To identify the nuclease activity, a DNA-native-PAGE assay was performed according to the method of Kwon and Kim (1998). Briefly, sodium dodecylsulfate-free $7 \%$ polyacrylamide gels were co-polymerized with supercoiled plasmid DNA (pGEM-T vector, $3.0 \mathrm{~kb}$, Promega, Madison, USA) at a final concentration of $150 \mu \mathrm{g} /$ $\mathrm{ml}$. The recovered culture medium or cell lysates that contained $10 \mu \mathrm{g}$ protein were loaded into each well and electrophoresed at $4^{\circ} \mathrm{C}$. After electrophoresis, the gels were washed three times in distilled water, and placed in a reaction buffer, which consisted of $20 \mathrm{mM}$ Tri- $\mathrm{HCl}$ (pH 7.0), $1 \mathrm{mM} \mathrm{CaCl}$, and $10 \mathrm{mM} \mathrm{MgCl}{ }_{2}$ (TCM buffer), at $37^{\circ} \mathrm{C}$ with gentle shaking. The gels were then stained in a TCM buffer that contained $1 \mu \mathrm{g} / \mathrm{ml}$ ethidium bromide at $37^{\circ} \mathrm{C}$ for $30 \mathrm{~min}$ and photographed on $302 \mathrm{~nm}$ transilluminator. The position of the nuclease activity was detected as a dark band on an orange background of the gel.

\section{Results and Discussion}

Induction of U937 cell differentiation The human monocyte U937 cells proliferate autonomously. However, the cells have retained the capacity to response to inducers of differentiation with cessation of growth and appearance of a more mature phenotype (Sundstrom and Nilsson, 1976). To prove that the PMA treatment of the U937 cells induces differentiation, we examined the viable potential of the PMAtreated and untreated cells by trypan blue exclusions (Fig. 1). When the U937 cells were cultured with $10 \mathrm{ng} / \mathrm{ml}$ PMA, the growth was completely inhibited without significantly affecting the cell viability (at least for $72 \mathrm{~h}$ ). On the other hand, cycloheximide showed a toxic effect that led to cell death. PMA-treatment of the cells was also accompanied by striking changes in the morphological characteristics, such as an increase in the cell size, a decrease in the nuclear/

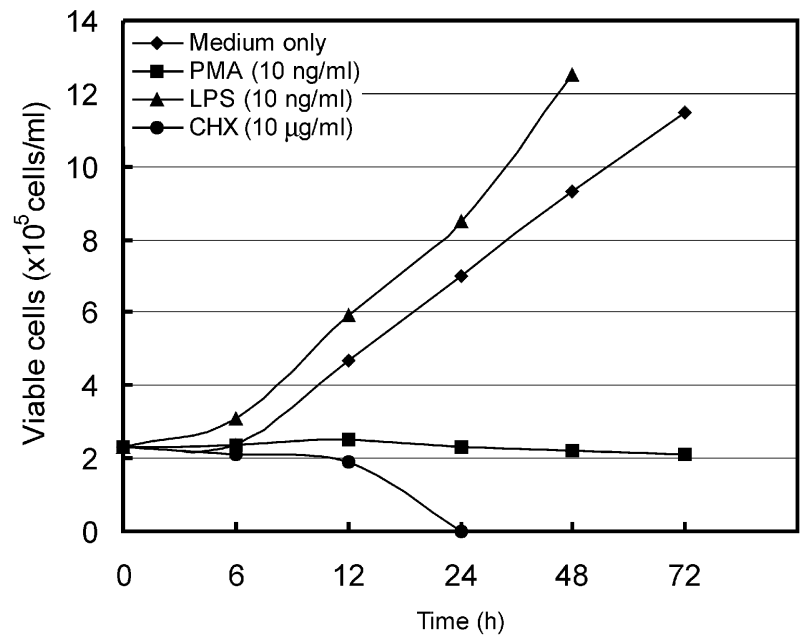

Fig. 1. Stimulations of U937 cells with different effectors. The U937 cells were seeded at $2.3 \times 10^{5}$ cells $/ \mathrm{ml}$. The number of viable cells was determined by trypan blue exclusion at the indicated time interval using a hemocytometer.

cytoplasmic ratio, a paler cytoplasm, more prominent granules, and a greater degree of vacuolization in the cytoplasm (data not shown). These observations are consistent with previous results from other investigators (Harris and Ralph, 1985).

PMA-induced nuclease production in U937 cells One of the signaling events that are associated with the differentiation that is induced by PMA was a nuclease activity that is synthesized and secreted in U937 cells. We employed a DNAnative-PAGE nuclease activity gel system to characterize the enzyme activity that is derived from the differentiated U937 cells (Fig. 2A). After $12 \mathrm{~h}$, enzyme activity began to appear in the culture medium. A significantly increased level of nuclease activity was detected $24 \mathrm{~h}$ after the PMA-treatment of the cells. Concomitantly with the growth inhibition (Fig. 1), the observed nuclease synthesis and secretion were dependent on the PMA concentration in its range of $0-10 \mathrm{ng} / \mathrm{ml}$ (Fig. 2B). Although detectable enzyme activity was induced at a lower PMA concentration, evident accumulation of nuclease activity was found both in the cell lysates and in the culture medium when the cells were treated with $10 \mathrm{ng} / \mathrm{ml}$ PMA. In addition to the U937 cell-derived nuclease activity, a fastmigrating nuclease band in the assay gel that corresponded to DNase I was also detectable in the culture medium that contained 10\% heat-inactivated FBS (Kwon and Kim, 1998).

Nuclease activity in U937 cells treated with PMA, LPS, cycloheximide We further analyzed the nuclease levels after stimulation of the U937 cells with different factors (Fig. 3). When the cells were stimulated with $10 \mathrm{ng} / \mathrm{ml}$ LPS, there was a significant induction of enzyme activity in the cell. However, there was no detectable nuclease activity released into the 
(A) Cell lysates

PMA: $0 \quad 6 \quad 12 \quad 2448 \mathrm{~h}$

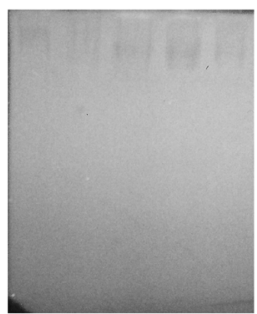

(B)

Cell lysates

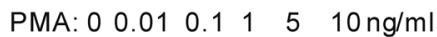

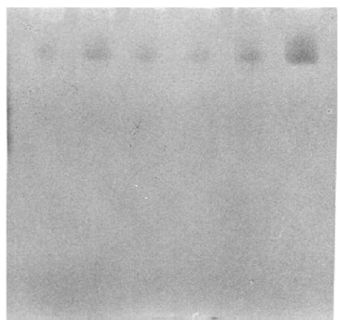

Fig. 2. DNA-native-PAGE analysis of the nuclease activity in PMA-treated U937 cells. (A) Nuclease activity in PMA (10 ng/ ml)-treated U937 cell lysates. The culture medium was estimated at the indicated time during the culture. (B) Biosynthesis and secretion of the nuclease activity in U937 cells were analyzed after a $24 \mathrm{~h}$-culture with the indicated PMA concentration.

culture medium. Neither the intracellular synthesis nor the secretion of the enzyme activity was observed in the cells that were treated with cycloheximide. Therefore, it is likely that the expression and secretion of the nuclease in U937 cells are controlled by specific extracellular stimulations.

We demonstrated in this work that U937 cells are differentiated and able to produce and release a particular nuclease activity by stimulation with PMA. In the previous study (Kwon and Kim, 1998), we identified a particular nuclease that is constitutively expressed and secreted by human B lymphoblastic IM9 cells. Since the nuclease is synthesized and secreted by U937 cells, an immune cell line of human origin, it is possible to speculate that the nuclease may play a role that is associated with defense mechanisms in vertebrates. There is increasing evidence that mammalian immune systems can distinguish bacterial DNA from vertebrate DNA, with bacterial DNA directly activating immune cells (Tokunaga et al., 1984; Messina et al., 1991; Stacey et al., 1996). Recent reports indicate that bacterial DNA has significant immunostimulatory effects on B cells (Krieg et al., 1995), natural killer cells (Ballas et al., 1996; Cowdery et al., 1996), and macrophages (Stacey et al., 1996; Stacey et al., 2000). The results of this study suggest that the PMA-induced nuclease activity in U937 cells may be involved in bacterial DNA degradation in order to produce the immunostimulatory DNA fragments in vertebrate. Further

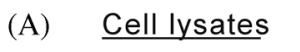

LPS: $0 \quad 6 \quad 12 \quad 24 \mathrm{~h}$

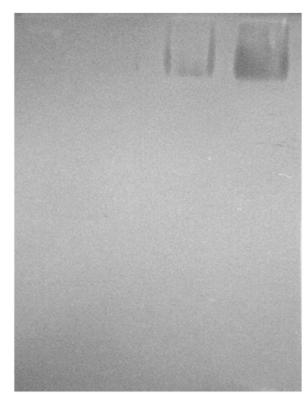

Culture medium

$0 \quad 6 \quad 12 \quad 24 \mathrm{~h}$

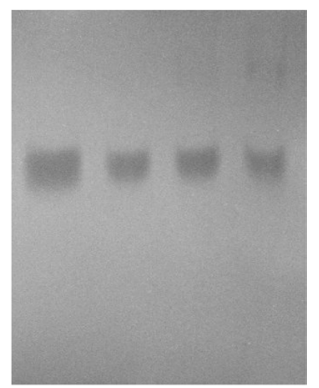

(B)

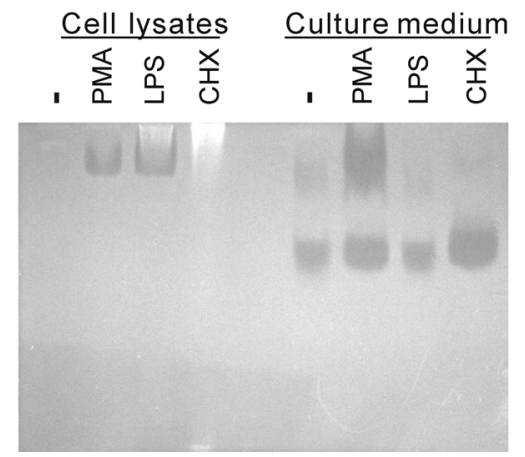

Fig. 3. DNA-native-PAGE analysis of the nuclease activity in U937 cells treated with stimulatory factors. (A) Nuclease activity in LPS (10 ng/ml)-treated U937 cell lysates. The medium was estimated at the indicated time during the culture. (B) U937 cells were cultured in a RPMI 1640 medium that contained 10\% FBS for $48 \mathrm{~h}$ in the absence (lane 1) or presence (lane 2) of $10 \mathrm{ng} / \mathrm{ml}$ PMA. The cells were cultured in the presence of $10 \mathrm{ng} / \mathrm{ml}$ of LPS (lane 3) or $10 \mu \mathrm{g} / \mathrm{ml}$ cycloheximide (CHX, lane 4) for $24 \mathrm{~h}$.

studies on the biochemical and molecular characteristics of the U937 cell nuclease will provide useful information for understanding the functional significance of the enzyme.

Acknowledgment This work was supported by a MOST grant CBM-01-A-7 from Korea.

\section{References}

Ballas, Z. K., Rasmussen, W. L. and Krieg, A. M. (1996) Induction of NK activity in murine and human cells by $\mathrm{CpG}$ motifs in oligodeoxynucleotides and bacterial DNA. $J$. Immunol. 157, 1840-1845.

Cowdery, J. S., Chace, J. H., Yi, A.-K. and Krieg, A. M. (1996) Bacterial DNA induces NK cells to produce IFN- $\gamma$ in vivo and increase the toxicity of lipopolysaccharides. J. Immunol. 156, 4570-4575.

Han, S.-S., Keum, Y.-S., Seo, H.-J. and Surh, Y.-J. (2002) Curcumin suppresses activation of NF- $\mathrm{KB}$ and AP-1 induced by phorbol ester in cultured human promyelocytic Leukemia cells. J. Biochem. Mol. Biol. 35, 337-342. 
Hass, R., Bartels, H., Topley, N., Hadam, M., Kohler, L., GoppeltStrube, M. and Resch, K. (1989) TPA-induced differentiation and adhesion of U937 cells: changes in ultrastructure, cytoskeletal organization and expression of cell surface antigens. Eur. J. Cell Biol. 48, 282-293.

Kim, S. Y., Kim, R. H., Huh, T.-L. and Park, J.-W. (2001) $\alpha-$ Phenyl- $N$ - $t$-butylnitrone protects oxidative damage to HepG2 cells. J. Biochem. Mol. Biol. 34, 43-46.

Kim, Y.-S., Ha, K.-S., Kim, Y.-H. and Bae, Y.-S. (2002) The ring$\mathrm{H} 2$ finger motif of CKBBP1/SAG is necessary for interaction with protein kinase CKII and optimal cell proliferation. $J$. Biochem. Mol. Biol. 35, 629-636.

Krieg, A. M., Yi, A.-K., Matson, S., Waldschmidt, T. J., Bishop, G. A., Teasdale, R., Koretzky, G. A. and Klinman, D. M. (1995) CpG motifs in bacterial DNA trigger direct B-cell activation. Nature 374, 546-549.

Kwon, H.-J. and Kim, D.-S. (1998) Identification of an endonuclease secreted by human B lymphoblastic IM9 cells. Int. J. Biochem. Cell Biol. 30, 217-223.

Kwon, H.-J. and Kim, D.-S. (1998) Properties of the endonuclease secreted by human B lymphoblastic IM9 cells. J. Biochem. Mol. Biol. 31, 106-110.

Messina, J. P., Gilkeson, G. S. and Pisetsky, D. S. (1991) Stimulation of in vitro murine lymphocyte proliferation by bacterial DNA. J. Immunol. 147, 955-962.

Nadano, D., Yasuda, T. and Kish, K. (1993) Measurement of deoxyribonuclease I activity in human tissues and body fluids by a single radial enzyme-diffusion method. Clin. Chem. 39, 448-452.

Pisetsky, D. S. (1996) The immunologic properties of DNA. J. Immunol. 156, 421-423.

Ribeiro, J. M. and Carson, D. A. (1993) $\mathrm{Ca}^{2+} / \mathrm{Mg}^{2+}$-dependent endonuclease from human spleen: purification, properties, and role in apoptosis. Biochemistry 32, 9129-9136.

Shak, S., Capon, D. J., Hellmiss, R., Marsters, S. A. and Baker,
C. L. (1990) Recombinant human DNase I reduces the viscosity of cystic fibrosis sputum. Proc. Natl. Acad. Sci. USA 87, 9188-9192.

Stacey, K. J., Sweet, M. J. and Hume, D. A. (1996) Macrophages ingest and are activated by bacterial DNA. J. Immunol. 157, 2116-2122.

Stacey, K. J., Sester, D. P., Sweet, M. J. and Hume, D. A. (2000) Macrophage activation by immunostimulatory DNA. Curr. Top. Microbiol. Immunol. 247, 41-58.

Sundstrom, C. and Nilsson, K. (1976) Establishment and characterization of a human histiocytic lymphoma cell line (U937). Int. J. Cancer 17, 565-577.

Tokunaga, T., Yamamoto, H., Shimada, S., Abe, H., Fukuda, T., Fujisawa, Y., Furutani, Y., Yano, O., Kataoka, T., Makiguchi, N. and Suganuma, T. (1984) Antitumor activity of deoxyribonucleic acid fraction from Mycobacterium bovis BCG. I. Isolation, physicochemical characterization, and antitumor activity. J. Natl. Cancer. Inst. 72, 955-962.

Yasuda, T., Awazu, S., Sato, W., Iida, R., Tanaka, Y. and Kish, K. (1990) Human genetically polymorphic deoxyribonuclease: purification, characterization, and multiplicity of urine deoxyribonuclease I. J. Biochem. 108, 393-398.

Yasuda, T., Nadano, D., Awazu, S. and Kishi, K. (1992) Human urine deoxyribonuclease II (DNase II) isoenzymes: a novel immunoaffinity purification, biochemical multiplicity, genetic heterogeneity and broad distribution among tissues and body fluids. Biochem. Biophys. Acta 1119, 185-193.

Yasuda, T., Sawazaki, K., Nadano, D., Takeshita, H., Nakanaga, M. and Kish, K. (1993) Human seminal deoxyribonuclease I (DNase I): purification, enzymological and immunological characterization and origin. Clin. Chim. Acta 218, 5-16.

Zeng, Z., Parmelee, D., Hyaw, H., Coleman, T. A., Su, K., Zhang, J., Gentz, R., Ruben, S., Rosen, C. and Li, Y. (1997) Cloning and characterization of a novel human DNase. Biochem. Biophys. Res. Commun. 231, 499-504. 